\title{
Direitos Humanos, migração e refúgio: Temas pertinentes para a profissão de Serviço Social
}

\section{Human Rights, Migration and Refuge: Relevant issues to the Social Work profession}

\author{
Lisarb Valéria Montes D'Oco* \\ Míriam Thais Guterres Dias ${ }^{* *}$
}

\begin{abstract}
Resumo: Este artigo tem como mote principal abordar as temáticas de direitos humanos, migração e refúgio e a sua relação com o Serviço Social. Elucidam-se a concepção de direitos humanos, de uma perspectiva histórica internacional, até os dias atuais, no Brasil e a relação dessa temática com os movimentos sociais, as legislações nacionais e internacionais e as políticas de direitos humanos no País. Posteriormente, situa-se o Serviço Social nessa temática, quanto às lutas pela sua defesa, à formação profissional e à produção teórica da categoria profissional. Pretende-se colaborar para a difusão dos direitos humanos como uma diretriz do trabalho dos profissionais do Serviço Social.
\end{abstract}

Palavras-chave: Direitos Humanos. Migração. Serviço Social.

\begin{abstract}
This article's main theme addresses the issue of human rights, migration and refugee and their relation to social work. It elucidates the conception of human rights from an international and historical perspective until the present day in Brazil. It also clarifies the relation of this subject to social movements, national and international laws and human rights policies within Brazil. After that it contextualizes the social work in this subject, for the struggle for its defense, the professional formation and the theoretical production in the professional category. The article intended to cooperate in the dissemination of human rights as a guideline for the work of professional social workers.
\end{abstract}

Keywords: Human Rights. Migration. Social Work.

Recebido em: 20/06/2016. Aceito em: 07/09/2016

\footnotetext{
"Mestranda pelo Erasmus Mundus Master Advanced Development in Social Work (ADVANCES), Especialista em Ética e Educação em Direitos Humanos (UFRGS), Assistente Social. E-mail: lisarbdoco@gmail.com.

"Docente do curso de Serviço Social e do Programa de Pós-Graduação em Política Social e Serviço Social da Universidade Federal do Rio Grande do Sul, Doutora em Serviço Social e Mestre em Serviço Social pela PUCRS. E-mail: miriamtgdias@gmail.com
} 


\section{Introdução}

Esta produção faz uma reflexão sobre o processo histórico e a relevância dos direitos humanos no Brasil, contextualizado nos marcos internacionais, para se discutir sobre migração e refúgio e, posteriormente, situar o Serviço Social nessa temática, quanto às lutas pela sua defesa e a produção teórica na categoria profissional.

Dialoga-se no sentido de uma perspectiva histórico-crítica, entendendo os direitos humanos como um processo histórico que nasceu nas bases do liberalismo francês do século XIII, mas que avança, sobretudo com a luta das classes trabalhadoras na reivindicação de garantias sociais, até os dias atuais. O texto está orientado, tanto no plano político quanto no normativo, pela compreensão contemporânea de direitos humanos indivisíveis, universais e interdependentes.

Uma discussão sobre o tema da migração e do refúgio no mundo contemporâneo faz-se necessária, bem como sua emergência para o trabalho dos assistentes sociais. Com o processo de globalização e neoliberalismo, aumenta a busca pelo controle de novos mercados (grandes conglomerados econômicos, através de fusões, incorporações, de concentração de riqueza e poder), intensificando a flexibilização das leis de trabalhistas, a terceirização dos serviços e as privatizações, as quais ganham amplo espaço, refletindo as novas transformações no mundo do trabalho. Além disso, as guerras, as mudanças climáticas, as catástrofes, o terrorismo e outros fatores influenciam as pessoas a buscarem novos locais para se fixar, a fim de encontrar trabalho, moradia, segurança e paz. É dessa forma que se chama atenção para a essa discussão, cujo tema tem reflexo cada vez maior na sociedade brasileira.

Pretende-se arrazoar sobre a referência dos direitos humanos tanto na formação profissional em Serviço Social quanto na sua produção teórica, as quais são inter-relacionadas, uma vez que a formação profissional está calcada nos referenciais teóricos que servem de subsídio para a prática profissional. Do mesmo modo, é a partir dessa práxis que se criam condições para sua análise teórica. Por fim, o fechamento do artigo retoma a relação do Serviço Social e dos direitos humanos com a atual questão de imigração e refúgio, como forma de reflexão e aprofundamento do tema.

\section{Direitos humanos: de uma perspectiva histórica internacional até os dias atuais, no Brasil}

A passagem da Idade Média para a Idade Moderna europeia conota inúmeras transformações sociais, políticas, econômicas e culturais. Enquanto, na Idade Média, a sociedade era permeada por camadas sociais estanques (sem possibilidades de mobilidades social e econômica), na Idade Moderna, foi-se ampliando, gradativamente, o processo de contestação à ordem social vigente, o feudalismo. Após superar o absolutismo e os resquícios do feudalismo, a nova classe social detentora do poder, a burguesia, impôs novas formas de relações sociais, conformando, consequentemente, o Estado liberal e o modo de produção capitalista. Essas transformações retratam como, mais tarde, os seres humanos se constituíram como sujeitos de direitos.

A Idade Moderna apresentou uma nova visão de mundo progressista, com ideias de desenvolvimento da sociedade e a busca pela racionalidade (MONDAINI, 2011). É a era do desenvolvimento do mercantilismo, bem como do surgimento de movimentos culturais, filosóficos e científicos de contestação social. Destacam-se o surgimento e o ascenso econômico da classe burguesa e a Revolução Industrial como episódios fundamentais no estudo dos direitos humanos.

Dos pontos de vista sociocultural e religioso, podem ser apontados o Renascimento e a Reforma Protestante como episódios em que se ousou desconstruir os valores conservadores advindos do período feudal e fundamentados pela Igreja Católica. A íntima relação desses movimentos com o desenvolvimento do mercantilismo e do novo mundo urbano foi ímpar no distanciamento dos costumes da Idade Média.

Os acontecimentos históricos ocorridos na Idade Moderna evidenciam uma sociedade permeada por novos conflitos e contradições, que desencadearam inovações sócio-históricas, momento em que "[...] o homem começa a tomar consciência de sua situação histórica" (ODALIA, 2010, p. 160). A nova ordem econômica que se instaurou nesse período, denominada de capitalismo (na sua primeira fase comercial), 
impôs novos padrões econômicos e relações sociais nunca experienciados até o momento (DORNELLES, 2005).

A burguesia, pautada nas inovadoras ideias de liberdade e racionalidade, detinha o poder econômico e político de forma ascendente e, com isso, empenhava-se em obter cada vez mais a liberdade para a acumulação e a circulação do capital e a contratação da força de trabalho. Cabe mencionar que o conceito de liberdade, para a classe burguesa, é concebido como o direito do indivíduo de existir limitado a si mesmo, ou seja, preconiza o direito à propriedade privada e, como exemplificam Forti, Marcosin e Forti (2011, p. 38), o processo de liberdade, na ótica da burguesia, representa "[...] o homem não se libertar da religião, mas obter liberdade religiosa [...]; não se emancipar do egoísmo da indústria, mas garantir a liberdade industrial".

Nesse complexo período de conformação do capitalismo, surgem os primeiros direitos civis e políticos (COUTO, 2004). Baseados na concepção iluminista, esses direitos estavam relacionados a cada sujeito de forma individual, não sendo considerados os processos sociais e históricos para sua aplicação. Segundo Trindade (2011), essa concepção inicial de direitos empregava a igualdade meramente jurídica, assegurando a propriedade privada como direito individual ilimitado.

No século XVIII, a Independência dos Estados Unidos tornou-se fato notável com a sua Declaração de Independência, documento que afirmava alguns dos principais ideais da época, como o direito à vida, à liberdade, à felicidade e à igualdade entre os homens. Aproximadamente uma década depois, a Europa veio a assistir, com a Revolução Francesa, a completa consolidação do Estado burguês, e, na Revolução Industrial inglesa, a definitiva separação entre capital e trabalho, ou seja, a conformação da sociedade de classes (VICENTINO; DORIGO, 1997).

Nessa fase, a burguesia já consolidada produziu a superestrutura necessária para o desenvolvimento de novas forças produtivas (NETTO; BRAZ, 2010). Esse sistema tem a produção de mercadorias como o centro da vida econômica e, como características principais, a expansão das fábricas e as novas relações de trabalho, como a substituição do labor manual pelo uso de máquinas a vapor e o controle e a padronização da produção. Destaca-se sobretudo a formação de uma nova classe social, a classe proletária.

Segundo Bobbio (1992), foi com a Revolução Industrial que se instituiu o direito ao trabalho. No entanto, o trabalho oferecido aos proletários estava baseado na relação de exploração. Tal condição era possível naquele momento, uma vez que os donos dos meios de produção (burgueses) usufruíam da insígnia de liberdade para estipular regras de mercado, como as horas de trabalho e os salários dos trabalhadores.

A migração em massa pela busca de trabalho formou os primeiros territórios urbanos, as cidades, e um contingente de trabalhadores (homens, mulheres, crianças, idosos), os proletários, que passaram a viver em locais com péssimas condições de moradia. Nessa fase do capitalismo, as condições de vida e de trabalho eram caracterizadas pela miséria, sem legislação trabalhista, e a exploração era ainda maior com relação às mulheres e às crianças. Com o passar do tempo, a numerosa mão de obra propiciou o excedente de trabalhadores, os quais passaram a viver marginalizados.

Com a consolidação do capitalismo e a relação contraditória entre as demandas do capital e as dos trabalhadores, criaram-se as condições objetivas para a identificação das lutas da classe proletária. Pouco a pouco, foi incluída, em suas pautas, a luta por melhores condições de trabalho e garantia de proteção.

A criação de sindicatos, por exemplo, é um dos resultados do esforço desses trabalhadores na reivindicação de direitos, os quais passaram a interferir nas estruturas das organizações burguesas. O direito ao trabalho e, posteriormente, à proteção social são frutos das lutas dos trabaIhadores como resposta às transformações ocasionadas pela revolução industrial (MARTINELLI, 1989). Se as ações empreendidas pela classe burguesa inauguraram os direitos civis e políticos, as manifestações realizadas pelos trabalhadores das fábricas e do campo, no auge do capitalismo industrial, trouxeram à tona a reivindicação dos direitos sociais (COUTO, 2004).

O século $X X$ foi marcado pela disputa entre países pela conquista territorial, política e econômica que ocasionou a Primeira Guerra Mundial (1914-18) e, posteriormente, a Segunda Guerra Mundial (1939-45). Ressalta-se a Segunda Guerra Mundial como um dos maiores e mais trágicos 
momentos relativos à violação da dignidade e dos direitos humanos. Pautado também na lógica de rivalidade entre as nações por interesses de expansão territorial e com o incremento da presença de Estados totalitários, esse período hostil testemunhou uma perda em massa de seres humanos de várias nacionalidades.

Os anos seguintes à Segunda Guerra Mundial foram revelando as infrações e as atrocidades ocorridas em sua consequência, possibilitando, assim, uma nova visão acerca da necessidade de proteção internacional dos direitos humanos.

Foi a reação às barbáries cometidas pelo nazismo e pelo fascismo que, posteriormente à guerra, causou a consagração da dignidade da pessoa humana no plano internacional. Também consagrou tal princípio no plano interno, como o valor máximo dos ordenamentos jurídicos e princípio orientador da atuação estatal e dos organismos internacionais. (RITT; CAGLIARI, 2007, p. 42).

Foi, portanto, nesse período pós-guerra que se iniciou a criação de sistemas de proteção internacional, os quais exigem dos Estados posturas pacíficas e sem violações de direitos internos ou externos contra outras nações. Considera-se também a internacionalização dos direitos humanos como medida estratégica e preventiva ao surgimento de violações maciças, que poderiam ocasionar novas guerras (ALVES, 1994).

O processo de internacionalização surgiu com a instituição da Organização das Nações Unidas (ONU) no ano de 1945. No entanto, foi apenas com a Declaração Universal dos Direitos Humanos (DUDH) (ONU, 1948), apresentada em dezembro de 1948, que esses direitos foram realmente expressos e definidos (GORCZEVSKI, 2005). A DUDH tem como finalidade estabelecer regulamentações, em âmbito internacional, na defesa do combate às violações contra seres humanos e para a promoção da paz entre as nações.

ADUDH é uma representação da consciência histórica que a humanidade passou a ter dos próprios valores fundamentais e, para Piovesan (1998), introduz uma concepção moderna de direitos humanos, os quais se caracterizam por suas universalidade e indivisibilidade, dando ao indivíduo a qualidade de sujeito de direito internacional, com a possibilidade de reivindicar perante a uma instância superior (BOBBIO, 1992).

Uma vez que a Declaração Universal dos Direitos Humanos se constitui em um documento de orientação, foram criados dois pactos com status de convenções internacionais, o Pacto Internacional Sobre Direitos Civis e Políticos e o Pacto Internacional Sobre Direitos Econômicos, que tiveram suas redações aprovadas em 1966, porém entraram em vigor somente 10 anos depois. A DUDH e os Pactos dão sustentação à proteção internacional dos direitos humanos, indicando um compromisso jurídico aos Estados signatários, como é o caso do Brasil.

O Brasil, por ser um país demarcado pela colonização portuguesa, sofreu diversas consequências, que desembocaram em relações de desigualdade econômica e social até os dias atuais. No século XVI, a prática de doação de lotes de terra (chamados sesmarias) possibilitou a concentração fundiária, uma vez que eram concedidas grandes extensões territoriais a pessoas de confiança da Coroa Portuguesa (VICENTINO; DORIGO, 1997). A dizimação da população indígena local e a inserção do trabalho escravo africano também proporcionaram relações de disparidades sociais. Por outro lado, houve diversos momentos de resistência, em que a população lutou contra os governos ou as oligarquias para garantir direitos.

Mesmo considerando as reivindicações populares na história brasileira, é importante ter em vista que a discussão propriamente dos direitos humanos é recente neste país. Freire (2011) pondera que a problematização do debate acerca dos direitos humanos vem a ser um tema abordado nas agendas dos movimentos sociais e dos governos apenas a partir do século XXI. Para a autora, essa "[...] base da construção da agenda dos direitos humanos no Brasil é tardia e remete diretamente ao terrorismo de Estado do final do século $X X$ relacionado à questão da ditadura militar" (FREIRE, 2011, p. 153), ou seja, tal fato impulsiona a população às reivindicações que virão a ter os primeiros resultados posteriormente.

No final do século $X X$, a Constituição Federal (CF) de 1988 restabeleceu o Estado Democrático de Direito, fazendo com que uma série de prerrogativas sociais tenha sido garantida na legislação. A positivação dos direitos humanos na CF demonstra um notável avanço, porém as 
violações de direitos seguem acontecendo de maneira habitual. Tais problemas de infringência "[...] transcendem fronteiras, demonstrando uma necessidade permanente de luta para que eles possam ser guindados da 'folha de papel' e incorporados ao cotidiano" (CUNHA, 2000, p. 104).

Não obstante isso, o desafio posto é o rompimento com a cultura enraizada no largo período de tradicionais práticas autoritárias observadas ao longo da trajetória brasileira. De acordo com Cunha (2000), a omissão e a incapacidade do governo de controlar e acabar com a impunidade fragilizam as garantias constitucionais, fomentam a espiral da violência e originam a descrença quanto à capacidade do Estado de promover a cidadania.

Mesmo com avanços no que diz respeito aos tratados internacionais e às legislações de proteção aos seres humanos, é notável o agravamento de outras formas de violações aos direitos humanos no Brasil, que estão relacionadas diretamente com o modo de produção atual do capitalismo financeiro.

Importa mencionar o papel dos movimentos sociais, que se mobilizam constantemente para garantir os direitos dos sujeitos neste país. Segundo Gohn (2003, p. 13), os movimentos sociais podem-se traduzir nas "[...] ações coletivas de caráter sócio-político e cultural que viabilizam distintas formas da população se organizar e expressar suas demandas".

A partir dos anos 60, a opressora ditadura militar criou um grande tensionamento entre governos e sociedade civil. Grandes cidades foram palcos de lutas, agitadas por protestos, passeatas, greves e atos públicos protagonizados por estudantes, trabalhadores operários, intelectuais e setores da Igreja Católica, que tinham como ponto em comum a luta pelas liberdades democráticas.

Durante a transição para a democracia no Brasil (1979-88) e por quase duas décadas, os temas de direitos humanos suscitaram reações depreciativas, frequentemente associados à defesa dos direitos de bandidos. No entanto, com a retomada da democracia no País, no final dos anos 80 , houve o surgimento dos novos movimentos sociais (MONTAÑO; DURIGUETTO, 2011). Esses movimentos têm como uma de suas características a resistência contra o neoliberalismo, na qual expõem as contradições do capitalismo, não só com relação à exploração dos trabalhadores das cidades e do campo, como também dos povos originários e da natureza como um todo.

A abertura democrática, somada às visíveis contradições do capitalismo, em sua fase neoliberal, proporcionou uma maior visibilização dos direitos humanos. Enquanto o avanço do capitalismo financeiro e informacional confere precarização às relações de trabalho, por outro lado, as organizações populares, as entidades do terceiro setor, bem como a criação de legislações, a adesão aos tratados internacionais e a implementação de políticas públicas, vêm somar lutas em prol dos direitos humanos.

Em linhas gerais, é possível dizer que os movimentos sociais se constituem em ações coletivas que se originam diante de alguma insatisfação e têm o objetivo de resistir contra ela. Nas palavras de Montaño e Duriguetto (2011), os movimentos conhecidos como clássicos têm a ver com as lutas sindicais e trabalhistas (relação entre capital e trabalho) ou, a partir do século XIX, com os que se articulam na luta pela conformação de uma nova ordem social (socialistas ou anti-imperialistas). Os chamados "novos movimentos sociais" vêm a ser uma soma aos movimentos clássicos ou "alternativos aos movimentos de classes tradicionais e aos partidos políticos de esquerda" (MOTAÑO; DURIGUETTO, 2011, p. 248).

O envolvimento de movimentos sociais na defesa de direitos é de longa data, já as organizações não governamentais (ONGs) são entidades mais contemporâneas, de caráter institucionalizado, com estatuto jurídico de entidade privada sem fins lucrativos. As ONGs consolidaram-se, no cenário brasileiro, a partir dos anos 80 e 90 do século XX, "atuando próximas aos movimentos sociais e dando os primeiros passos como ator social na cena pública" (PAZ, 1997).

Destaca-se o papel desses grupos na defesa e na consolidação dos direitos humanos, tanto em âmbito nacional quanto internacional. As ONGs de direitos humanos constituem o conjunto de variadas instituições, de cunho doméstico ou internacional, com propósitos e formas de atuação diferenciadas em relação à proteção, à promoção e ao monitoramento dos direitos humanos. A utilização da terminologia ONG deve-se à sua atuação independente dos Estados-nação 
(CULLETON; BRAGATO; FAJARDO, 2009, p. 227).

Essas entidades também se dedicam à realização de pesquisas e dossiês, com o objetivo de acompanhar como estão os índices de violações nos países. Os dados encontrados auxiliam a realização de denúncia em ordem mundial, no sentido de pressionar os governos culpados. Outra função comumente realizada por ONGs é o planejamento ou a execução de projetos contratados por Governos ou empresas privadas.

Com a instalação do Estado democrático brasileiro, tem-se a perspectiva de um avanço com relação à liberdade de expressão e a uma nova autonomia para a criação de leis e ações, resultando na garantia dos direitos de toda a população. Como característica marcante, a Constituinte de 1988 demonstra um rompimento com o passado (GORCZEVSKI, 2005). Ao se analisar a redação da Carta Constitucional, é possível verificar que ela foi elaborada com o pressuposto de contestar a ordem existente, buscando afastar-se do que estava instituído até então. É possível observar a presença dos direitos humanos nesse documento, principalmente no título II - Dos direitos e garantias fundamentais, que compreende os direitos e deveres individuais e coletivos, os direitos sociais, os direitos referentes à nacionalidade e os direitos políticos, isso abrange do artigo $5^{\circ}$ ao 16 .

Também se enfatiza, como outra característica da Constituição brasileira de 1988, que o "[...] marco jurídico de institucionalização dos direitos humanos e da transição democrática no país, ineditamente, consagra o primado do respeito aos direitos humanos, como paradigma propugnado para a ordem internacional" (PIOVESAN, 1998, p. 88). Importa colocar-se que o Brasil passou a participar ativamente de foros internacionais que tratam da matéria dos direitos humanos (CULLETON; BRAGATO; FAJARDO, 2009). Um importante exemplo é a participação do Governo brasileiro na Conferência Mundial de Direitos Humanos, no ano de 1993, em Viena. $\mathrm{O}$ objetivo desse evento foi discutir as grandes violações presentes no Globo, e teve como um de seus principais encaminhamentos a orientação para que os países criassem planos nacionais de direitos humanos.
Além da legislação que ampara a regulação dos direitos, é importante mencionar sua inserção nas políticas públicas para garantia de sua promoção. Segundo Bucci (2001), existe uma forte relação entre o tema das políticas públicas e o dos direitos humanos, pois uma das características do movimento de ampliação do conteúdo jurídico para a defesa da dignidade humana é a multiplicação das demandas por direitos. Os direitos humanos, independentemente de serem civis, políticos, econômicos, sociais ou culturais, exigem a proteção do Estado, através da adoção de políticas que materializem, na vida dos sujeitos sociais, suas exigibilidade e proteção (LIMA JR., 2002).

No Brasil, o Executivo iniciou a promoção e a articulação de políticas públicas de direitos humanos por meio da realização da I Conferência Nacional de Direitos Humanos (1996), a qual propiciou a implementação do Programa Nacional de Direitos Humanos (PNDH). Nas palavras de Pinheiro e Neto (1997), o PNDH articula e fortalece uma mudança na ideia de direitos humanos, já partilhada pelas organizações de direitos humanos, no entanto,

[...] pela primeira vez adotada e defendida pelo governo brasileiro na história republicana, segundo a qual os direitos humanos não são apenas os direitos civis e políticos, mas também os direitos econômicos, sociais e culturais, tanto dos indivíduos quanto da coletividade (PINHEIRO; NETO, 1997, p. 123).

Na sequência, a estratégia foi criar a Secretaria de Estado de Direitos Humanos (1997) e promover ações gerais do $\mathrm{PNDH}$, incluindo uma segunda fase do Programa, em 2002, com foco nos direitos econômicos, sociais e culturais. Posteriormente, foram criadas a Secretaria Especial de Políticas Para as Mulheres e a Secretaria de Promoção da Igualdade Racial (2003), quando também foram realizadas ações de combate ao trabalho escravo e à violência no campo (ALMEIDA, 2011).

Destacam-se a criação do Disque Direitos Humanos, a implantação do Programa Brasil sem Homofobia e as ações para a proteção de defensores de direitos humanos e de educação em direitos humanos, ainda que com pouca previsão orçamentária, no contingenciamento dos gastos públicos e na dificuldade de articulação com a 
sociedade civil organizada, mostrando que "[...] a chegada de um governo de centro-esquerda ao poder não havia alterado a realidade de execução de políticas públicas de direitos humanos no Brasil [...]" (INESC, 2005).

A criação da terceira edição do Programa Nacional de Direitos Humanos (PNDH-3) foi fruto do processo da $11^{\text {a }}$ Conferência Nacional de Direitos Humanos, no ano de 2008. Nesse sentido, o PNDH-3 inovou, ao incluir diretrizes e ações destinadas à proteção da terra e dos territórios tradicionais e ao direito ao meio ambiente e ao desenvolvimento sustentável.

A $12^{\text {a }}$ Conferência Nacional de Direitos Humanos, intitulada Direitos Humanos Para Todas e Todos: Democracia, Justiça e Igualdade, aconteceu no mês de abril de 2016. Essa CNDH deu seguimento às quatro conferências nacionais temáticas, a saber, a $10^{a}$ Conferência Nacional dos Direitos da Criança e do Adolescente, a $4^{\text {a }}$ Conferência Nacional dos Direitos da Pessoa Idosa, a $3^{\text {a }}$ Conferência Nacional de Políticas Públicas de Direitos LGBT e a $4^{\text {a }}$ Conferência Nacional dos Direitos da Pessoa com Deficiência.

Nos últimos 10 anos, muitas Conferências Nacionais de Direitos Humanos com enfoque na proteção de direitos vêm sendo realizadas. Em muitas delas, é citado o tema das migrações, assunto que, neste artigo, será analisado, como o fenômeno da mobilidade humana, transversal a diversos debates sociais (BRASIL, 2014). Ainda assim, identificam-se facilmente um vazio que acompanha a própria história recente das políticas migratórias no País e uma criticável invisibilidade das populações migrantes, predominante até há pouco tempo.

\section{Migração e refúgio no Brasil: breve histórico, conceitos e a importância do avanço nas políticas públicas}

Uma questão cuja abordagem é necessária refere-se à presença de estrangeiros no Brasil e, não menos importante, à demanda contemporânea da vinda de migrantes em situação de refúgio. Para se abordar essa questão, primeiramente, é preciso situar, historicamente, como esses fenômenos se apresentam no País. A formação populacional do Brasil foi determinada por uma série de povos de diferentes culturas. O período colonial foi marcado pela ocupação de portugueses neste vasto território, o qual já era habitado por diversas tribos indígenas. Ainda no início do século XVI, a intensificação de atividades econômicas fez com que os portugueses trouxessem mão de obra escrava da África. A partir de 1850, com a proibição do tráfico de escravos e frente à necessidade de trabalhadores na agricultura e na indústria (em fase de estabelecimento), ocorreu a vinda de novos trabalhadores para o Brasil.

A imigração, em maior parte, de europeus e, em menor número, de outras nacionalidades deu-se a partir da metade do século XIX. Além da necessidade de mão de obra, os movimentos migratórios partiam de uma ideia de controle do Governo associado à intenção de "branqueamento" da população. Conforme consta na literatura, o Brasil recebeu cinco milhões de migrantes, principalmente italianos, portugueses, espanhóis e alemães, como também japoneses e outros grupos em menor quantidade, como russos, austríaCOs, sírio-libaneses e poloneses (COGO; BADET, 2013). Essa perspectiva buscava garantir a vinda de "trabalhadores brancos e sadios, agricultores exemplares, oriundos do meio rural europeu" (COGO; BADET, 2013, p. 20).

Na metade do século XX, com o advento da Segunda Guerra Mundial, muitas pessoas oriundas de locais em crise buscaram novas oportunidades de vida. Por temor de perseguição política ou religiosa, grande número de famílias optou por fugir e solicitar acolhimento à outra nação, ocorrendo um deslocamento estimado em mais de 40 milhões de pessoas. Em 1951, a Organização das Nações Unidas decidiu criar um órgão subsidiário responsável pela proteção dos refugiados, chamado de Alto Comissariado das Nações Unidas Para os Refugiados (ACNUR), e articulou a Convenção Relativa ao Estatuto dos Refugiados, principal instrumento internacional referente aos refugiados. Esse documento definiu o conceito clássico de refugiado, aplicável a qualquer pessoa que, em consequência dos acontecimentos ocorridos antes de $1^{\circ}$ de janeiro de 1951 e receando com razão ser perseguida em virtude da sua raça, religião, nacionalidade, filiação em certo grupo social ou das suas opiniões políticas, se encontre fora do país de que tem a nacionalidade e não possa ou, em virtude daquele receio, não queira pedir a proteção daquele país; ou que, se não tiver nacionalidade e estiver fora do país no qual tinha a sua residência habitual 
após aqueles acontecimentos, não possa ou, em virtude do dito receio, a ele não queira voltar.

O Brasil foi signatário da Convenção de 1951, responsabilizando-se em acolher refugiados, porém limitando o acolhimento apenas para refugiados europeus em seu território (ANDRADE, 1996). Porém, nas décadas seguintes, as quais foram marcadas pela ditadura militar na América Latina, houve um acolhimento aos refugiados quase nulo ou bem limitado no Brasil.

Para dar mais amplitude aos Dispositivos da Convenção de 1951, foi assinada, em 1984, a Declaração de Cartagena, que reiterou a necessidade de os países da região da América Latina ampliarem o conceito de refugiado

[...] a toda aquela pessoa que tivesse fugido de seu país porque a sua vida, segurança ou liberdade tenham sido ameaçadas pela violência generalizada, agressão estrangeira ou conflitos internos, violação maciça dos direitos humanos ou outras circunstâncias que tenham perturbado gravemente a ordem pública (DECLARAÇÃO DE CARTAGENA, 1984, p. 3).

O período de abertura democrática no Brasil possibilitou uma retomada às questões voltadas aos refugiados. Na CF de 1988, está assegurada aos estrangeiros residentes no País condição jurídica paritária à dos brasileiros no que concerne à aquisição e ao gozo de direitos civis, como afirma o caput do artigo $5^{\circ}$, que garante a inviolabilidade do direito à vida, à liberdade, à igualdade, à segurança. Nos anos 90, o acolhimento de refugiados provindos de vários continentes intensificou-se, quando houve um maior envolvimento em foros com o tema dos direitos humanos frente às organizações internacionais, período em que o País já apresentava mais de 1.000 refugiados em seu território (MOREIRA, 2008).

Posteriormente, com a instituição do Estatuto do Refugiado no Brasil, a Lei n 9.474/97, modernizou-se o conceito de refugiado. No parágrafo $1^{\circ}$ desse documento, consta:

Art. $1^{\circ}$ Será reconhecido como refugiado todo indivíduo que:

I - devido a fundados temores de perseguição por motivos de raça, religião, nacionalidade, grupo social ou opiniões políticas encontre-se fora de seu país de nacionalidade e não possa ou não queira acolher-se à proteção de tal país;
II - não tendo nacionalidade e estando fora do país onde antes teve sua residência habitual, não possa ou não queira regressar a ele, em função das circunstâncias descritas no inciso anterior;

III - devido a grave e generalizada violação de direitos humanos, é obrigado a deixar seu país de nacionalidade para buscar refúgio em outro país.

Reconhecidamente, o Brasil está entre os países que detêm legislação mais completa para abrigar e atender as necessidades dos refugiados.

Essa lei também é importante pela criação do Comitê Nacional Para Refugiados (Conare), que consolida a estrutura tripartite (instituições domésticas, organização internacional e Governo brasileiro), para tratar das questões de refúgio no Brasil. De acordo com Moreira (2008), os governos de Fernando Henrique Cardoso e o primeiro mandato de Lula evidenciaram uma preocupação com a questão dos refugiados, principalmente por estabelecer o Programa Regional de Reassentamento Solidário e pelo financiamento de auxílio fornecido aos refugiados no período.

Posto isso, reforça-se a diferenciação entre o conceito de migrante e o de refugiado. $\mathrm{O}$ processo de migração, como visto anteriormente, implica mudança de país por distintos motivos, como possibilidade de ascensão econômica e estudos; já o refúgio implica a migração forçada, onde há um movimento de pessoas em situação de coação, incluindo a ameaça de vida e de subsistência. No caso de refúgio, importa compreender, então, a situação de vulnerabilidade antes da migração (LUSSI, 2009), ou seja, as circunstâncias particulares de vulnerabilidade que forçaram o deslocamento, bem como os processos futuros na chegada em um novo território.

Pelo viés da proteção jurídica, mesmo que leis defendam os refugiados e possibilitem seu domicílio em qualquer lugar do território do Estado brasileiro, ainda são falhas e discriminatórias as políticas migratórias de diversas nações.

Migrações internacionais hoje como ontem, como ressalta ampla literatura clássica, é tema que pede debate sobre modelo de organização da economia política, lugar do trabalhador para tipos diferentes de setores no capitalismo, como o financeiro, sua globalização e como tais processos viriam afetando as 
condições de vida quer dos que migram quer dos que não migram. (CASTRO, 2008, p. 10).

Atualmente, no Mundo, estima-se a existência de mais de 200 milhões de migrantes internacionais, o que evidencia que uma em cada seis pessoas, na Terra, é migrante. ${ }^{1}$ Com relação ao número de refugiados, o relatório lançado em 20 de junho (Dia do Refugiado) de 2016 pelo ACNUR evidencia que são mais de 65 milhões em nível mundial, sendo $41 \%$ dessa população com idade inferior a 18 anos (GLOBAL TRENDS FORCED DISPLACEMENT IN 2016, 2016).

Desde o início dos anos 2000, em decorrência da estabilidade econômica vivida, o Brasil tem atraído um maior deslocamento de imigrantes e refugiados (COGO; BADET, 2013). Segundo a ACNUR, o número de refugiados reconhecidos no Brasil, hoje, é de $8.863,{ }^{2}$ oriundos de 79 nacionalidades. Essa situação cria novos desafios ao País, provocando a construção de possibilidades de respostas possíveis para oferecer condições de cidadania a essa população.

Os movimentos migratórios internacionais no Brasil, nos anos 2000, reforçam a tendência de configuração de espaços da migração, com a necessidade de diferentes olhares para as escalas e arranjos transnacionais aonde esses fluxos se processam, seus sentidos e repercussões dentro e fora das fronteiras territoriais. (BAENINGER, 2015, p. 79).

Chama atenção que as migrações atuais apresentam uma maior diversidade cultural, por conta da maior presença de grupos étnicos (COGO; BADET, 2013), bem como o grande percentual de mulheres migrantes, crianças e de pessoas que transitam em busca de trabalho e vida digna.

Os migrantes encontram-se em situação de vulnerabilidade em diversos níveis. Pode-se dizer que os processos de exclusão de seus direitos se dão no país de origem e, muitas vezes, também, quanto aos direitos humanos, econômicos, sociais

\footnotetext{
${ }^{1}$ Conforme o Observatório ACP das Migrações, é possível que a migração irregular não seja totalmente captada pelos censos nos países, assim, é importante estar a par dessas fraquezas, ao tirar conclusões dos dados (Observatório ACP das migrações, 2011).

2 Segundo a mesma fonte, até o ano 2015, mais de 28 imigrantes estavam aguardando seu processo de reconhecimento como refugiados.
}

e culturais, nos países de acolhida (CHIARELLO, 2012). Lussi (2009) defende a utilização do termo "migrantes em situação de vulnerabilidade", visto que essa condição não é inerente à pessoa migrante, mas à situação em que ela se encontra. Além disso, as pessoas em situação de migração estariam expostas pelas

[...] fragilidades e complexidades de sua situação psicofísica, jurídica e socioeconômica, enquanto migrante, a que determina as vulnerabilidades que podem causar, não somente formas genéricas de risco social, mas também ameaças bem específicas como deportação, tortura, perda de identidade e de equilíbrio psicológico ou até morte, para citar alguns exemplos (LUSSI, 2009, p. 2).

No que tange ao papel dos Estados, são condições que remetem à violação de direitos o enrijecimento das políticas migratórias e da concepção xenófoba dos controles de fronteira e o tratamento dado a quem se encontra irregular (LUSSI, 2009). Além disso, as questões que tangem os sistemas político e econômico das nações baseadas em uma lógica de mercado de capitais geram atrocidades cada vez mais devastadoras para as populações.

Os Estados nacionais, com poucas exceções, têm cada vez menos poder de controle e coerção sobre a globalização do crime organizado e sobre os subterfúgios ilícitos com os quais atuam as organizações criminosas e os especuladores financeiros. Tudo isso revela que a violência direta, provocada pelas guerras e o crime organizado, e a violência indireta, provocada pelo atual sistema econômico excludente, estão intimamente relacionadas e revelam a necessidade de considerar as responsabilidades morais dos atores destas duas formas de violência (CHIARELLO, 2012, p. 226).

Atualmente, organizações da sociedade civil, como entidades religiosas de proteções dos direitos humanos, associações de migrantes, as universidades e também atores individuais, ${ }^{3}$ estão envolvidas no reconhecimento de direitos dos migrantes (LUSSI, 2013). Muitas congregações religiosas e pastorais e pessoas carismáticas

\footnotetext{
${ }^{3}$ Lussi (2013) aponta três tipologias no envolvimento dos migrantes: (a) as redes pelos migrantes, (b) as ações sem redes e (c) as organizações de migrantes.
} 
acolheram pessoas envolvidas no fenômeno da mobilidade humana (migrantes, viajantes, romeiros, escravos, prófugos, exilados, encarcerados e outros), prestando seus serviços humanitários em prol dos necessitados. Várias dessas instituições de cunho religioso seguem atuando, algumas inclusive com status de organizações não governamentais. Além do atendimento direto, atualmente, essas instituições têm participado de atividades que envolvem a criação de políticas públicas, pressionando os governos nas três esferas para avanços tanto na legislação quanto no oferecimento de serviços de qualidade e oportunidades de trabalho para migrantes que se encontram no Brasil.

Embora o Brasil tenha recebido, em seu contexto histórico, uma grande população de imigrantes, é necessário ter em conta a conjuntura e os desafios atuais. Todo e qualquer problema de violação de direito que um imigrante ou refugiado venha a sofrer não deve ser tratado como um problema de cunho jurídico apenas, mas, sim, como uma questão migratória (LUSSI, 2014). Elenca-se, brevemente, dentre os fatores causais das migrações internacionais, a crescente vulnerabilidade por que passam as pessoas que migram, as quais encontram maiores dificuldades para a própria integração nas sociedades de acoIhida e se convertem em vítimas de violações dos direitos humanos como discriminações, situações de escravidão e tráfico de pessoas. ${ }^{4}$

Com relação às adversidades que se apresentam, Lussi (2014) lista três prioridades para seu enfrentamento: governança e um processo participativo de diálogo; o atendimento aos recém-chegados e aos que estão há um longo período; e, por último, o questionamento sobre qual a sociedade que queremos em termos de pluralidade.

As evidências empíricas das migrações internacionais para e do país demonstram a complexidade e heterogeneidade da imigração internacional neste século. Denotam os desafios teórico-metodológicos para explica-

\footnotetext{
${ }^{4}$ Demandas já discutidas através de reivindicações de brasileiros no exterior levaram, de uma forma muito embrionária, a migração para a agenda política, o que possibilitou um compromisso público de interlocução do Ministério de Relações Exteriores, que legitimou as "Comunidades de brasileiros e brasileiras no mundo" (LUSSI, 2013).
}

ções e análises das migrações de haitianos, chineses, coreanos, bolivianos, peruanos, paraguaios, imigrantes internacionais qualificados, imigrantes internacionais indocumentados, imigrantes refugiados, presentes nos espaços migratórios construídos a partir de nexos transnacionais no Brasil Imigrante do século 21. (BAENINGER, 2015, p.84).

Assim, considera-se cada vez mais urgente a busca de reflexão sobre como ocorrem as migrações nacionais na atualidade. As questões de migração devem constar na agenda para o alinhamento de uma política migratória brasileira, tanto no âmbito da compreensão do tema como para a elaboração de políticas públicas e sociais. Além disso, deve-se valorizar a experiência migrante como peça central para a elaboração de políticas (BRASIL, 2014). Tais ações poderão auxiliar na garantia mais efetivas de direitos para essa população e de avanços na realidade do cenário migratório.

\section{Serviço Social: produção teórica em direitos humanos, prática profissional e o trabalho com a população migrante}

Inicialmente, é necessário situar a profissão do Serviço Social, que emergiu no contexto do capitalismo industrial do século XIX, tendo, primeiramente, como base profissional ações ligadas à filantropia e à legitimação ideológica da ordem e a fragmentação de problemas. De acordo com lamamoto (2010, p. 97), a profissão "[...] surge e se desenvolve nos marcos do pensamento conservador, como um estilo de agir e pensar na sociedade capitalista", tendo como herança intelectual a doutrina social da Igreja e o conservadorismo europeu e incorporando, posteriormente, a sociologia funcionalista norte-americana.

Nas décadas de 70 e 80 do século $X X$, a profissão do Serviço Social instalou um processo de ruptura com esse conservadorismo, quando a resistência ao período ditatorial e o compromisso com a classe trabalhadora produziram o acento nos valores de emancipação e liberdade como a direção social da categoria profissional. Contudo é possível constatar-se que a temática de direitos humanos não se apresenta enquanto tema de maior interesse da categoria. Compreende-se que essa afirmação é bastante delicada de se 
fazer, no entanto, aqui serão trazidas argumentações a respeito dos possíveis motivos desse distanciamento.

Como forma de elucidar essa relação entre a categoria de assistentes sociais e os direitos humanos, apresenta-se a seguinte ponderação feita por Ruiz (2011, p. 71),

Duzentas pessoas em um auditório. Em sua quase totalidade, profissionais e estudantes de Serviço Social. Uma das palestrantes inicia sua intervenção com uma instigante questão: "Quantos de vocês atuam com direitos humanos?". Apenas $5 \%$ dos presentes levantaram a mão.

O pequeno retorno da categoria demonstra que ainda existe uma dificuldade de relacionar as demandas cotidianas da profissão com os direitos humanos. É possível apontar três teses distintas, as quais se apresentam neste artigo.

É provável que tenha a ver com a ideia de que tais direitos estejam atrelados à concepção liberal de direito. Essa ideia ainda é bastante presente no Serviço Social, uma vez que muitos autores pontuam essa relação, inclusive quando se referem aos "direitos humanos e sociais", insinuando que os direitos sociais não fazem parte dos direitos humanos. Em sua pesquisa, Mangini (2011) averigua que grande parte das produções teóricas acerca dos direitos humanos, nos periódicos da área, atenta para uma "crítica dos direitos humanos, como substrato do discurso ideo-burguês" (MANGINI, 2001, p. 122-123), sendo assim, a autora expõe que, ao partir dessa linha, o debate não se encaminha para o aprofundamento e a explicitação de seus fundamentos. Ao tratar esse tema, busca-se a reflexão de Meszáros (2008), quando o autor refere que o "[...] objeto da crítica em Marx não consiste nos direitos humanos enquanto tais, mas no uso dos supostos 'direitos do homem' como racionalização pré-fabricada das estruturas predominantes de desigualdade e dominação" (MESZÁROS, 2008, p. 161).

Outra interpretação a ser feita é a de que os direitos humanos diriam respeito à luta por direitos protagonizados pelos movimentos sociais, quando travam disputas contra os governos ou com entidades privadas, a fim de garantir seus direitos pautados nos princípios de dignidade, igualdade de direitos, justiça social e paz. Como muitos dos assistentes sociais têm seus vínculos de trabalho nas políticas governamentais (seguridade social, educação e habitação), tem-se uma provável ideia de que esses profissionais não identificam que trabalham com a matéria de direitos humanos.

Por fim, discute-se que os direitos humanos vêm sendo retratados de várias formas, enquanto conceito. O termo direitos humanos é utilizado regularmente pela mídia nas situações em que a violação do direito do sujeito chegou ao ponto mais extremo, como são os casos, por exemplo, do encarceramento, das situações de refúgio internacional, de tráfico humano ou das violações ocorridas nos períodos ditatoriais, fazendo com que o conceito pareça estar atrelado apenas às "situações limites" de violações de direito. $O$ mesmo termo também vem sendo empregado em veículos de comunicação com "[...] uma imagem falaciosa e pejorativa sobre os direitos humanos, prejudicando, assim, a afirmação desses direitos no país. Há muitos casos a se relatar, como os 'programas policiais' apelativos e sensacionalistas em muitas TVs brasileiras" (SPAGNUOLO, 2014, p. 1), fazendo que esse seja mencionado de maneira hostilizada.

Destarte, não se pretende buscar uma resolução ou resposta final para essas proposições. O que interessa aqui é levantar as possibilidades que possam explicar a ausência de um maior interesse pela área dos direitos humanos pelos assistentes sociais. Ainda assim, entende-se que as possibilidades levantadas não se contradizem e podem ser, inclusive, complementares, uma vez que a discussão dos direitos humanos é um tema bastante complexo e permeado por várias concepções teóricas e ideológicas.

Compreende-se que a vinculação da categoria aos direitos humanos está em todos os espaços sócio-ocupacionais do profissional do Serviço Social.

É difícil imaginar em que situações o Serviço Social não atue com direitos humanos. Mesmo sob limitações institucionais e conjunturais dimensões como as de elucidá-los aos usuários e contribuir para a apreensão da relação dos direitos com as legislações existentes estão no horizonte da atuação profissional no Brasil. Na concepção aqui defendida, portanto, é possível antever que todos os assisten- 
tes sociais atuam com direitos humanos (RUIZ, 2011, p. 80, grifos dos autores).

Os assistentes sociais estão inseridos em diversos lócus de trabalho, nos quais lidam, diariamente, com as diversas expressões da questão social. Essas expressões são fruto das contradições existes nas relações intrínsecas ao modo de produção capitalista, as quais representam violações diretas ou indiretas na vida dos sujeitos.

A questão social está na base da especialização do trabalho dos assistentes sociais. A partir desse campo, os profissionais são convocados a interferir nas relações sociais cotidianas dos sujeitos, de forma a buscar garantir os direitos destes últimos, os quais, na maioria das vezes, estão em situação de vulnerabilidade social e econômica. Esses direitos podem ser de diversas ordens, desde um direito civil, vinculado à autonomia, à liberdade e à segurança da pessoa, direito político ou direito social.

Reafirma-se que esses direitos são considerados aqui como indivisíveis, ainda assim, entende-se que cada um deles se refere a uma ação diferente, e é nesse sentido que se observa que, ao lidar com a garantia de direitos, muitas vezes, se estará atuando conjuntamente com outras variáveis desses direitos. Por exemplo, o direito à saúde é considerado um direito social, no entanto, para que tenha acesso a algum serviço de saúde, o sujeito exerce seu direito de ir e vir, que é um direito civil.

Dessa forma, compreende-se que os direitos devem ser analisados e tomados como direção da intervenção profissional na perspectiva dialética, isso quer dizer que, ao lidar com situações cotidianas na garantia de direitos, deve-se compreender que esses são oriundos de um processo histórico e que têm relação com os demais direitos. Assim, mesmo os direitos já consagrados de forma jurídica e que, em âmbito universal, estão em vigor ainda não dão conta de garantir os direitos das diversidades, ou seja, os direitos constitucionalizados apenas asseguram direitos a uma parcela da população.

A profissão de Serviço Social está cada vez mais envolvida com os novos direitos, os quais dizem respeito às reivindicações contemporâneas da população. Muitos autores, sobretudo da área jurídica, elencam esses novos direitos em ordens geracionais, assim como os direitos clássicos já constituídos na trilogia da Declaração Francesa (civil (liberdade), político (igualdade) ou social (fraternidade)), os quais seriam conhecidos comumente como direitos de quarta dimensão (biodireitos e bioética) ${ }^{5}$, de quinta dimensão (direitos de paz e democracia) e de sexta geração (informação correta e pluralismo) ${ }^{6}$ (BONAVIDES, 1993). Considera-se que o envolvimento da profissão com esses novos direitos resulta na perspectiva de uma visão de totalidade acerca dos sujeitos enquanto seres de direitos.

[...] é necessário entender, também, que a expressão sujeitos de direitos, tão utilizada pelos profissionais do Serviço Social, ao se referirem àqueles que atendem em seu trabalho, tem configuração histórica e pode não ultrapassar a lógica formal do direito positivo. Essa é a maneira de contribuir profissionalmente, sem abstrações para a defesa de direitos humanos e das conquistas civilizatórias (FORTI; MARCOSIN; FORTI; 2011, p. 50, grifos dos autores).

Nessa discussão a respeito do exercício profissional do Serviço Social, é importante que se atenha ao Conselho Federal de Serviço Social (Cfess) e seus entes regionais. O conjunto CfessConselhos Regionais de Serviço Social (Cress) caracteriza-se por defender o exercício profissional nos campos da orientação, da disciplina, da normatização e da fiscalização, além disso, busca promover políticas para a construção de uma de sociedade pautada no projeto ético-político da profissão.

Tanto o Conselho Federal quanto muitas das entidades regionais possuem comissões temáticas ampliadas de ética e direitos humanos. $A$ intenção dessas comissões ou grupos de trabalho (GTs) é alavancar o debate sobre o tema com todos os profissionais da categoria.

\footnotetext{
${ }^{5}$ Esses direitos dizem respeito ao futuro e à preservação da espécie humana, sendo criados por causa dos acontecimentos da Segunda Guerra Mundial e do Governo nazista, período em que foram realizados diversos experimentos genéticos e procedimentos médicos usados como argumento para o assassinato de muitos sujeitos inocentes.

${ }^{6}$ A explanação desses direitos dá-se como forma de referenciar em que instância se encontram as discussões a respeito da luta por direitos. Para mais informações acerca do assunto, ver Bonavides (1993).
} 


\section{do Cfess}

A Comissão de Ética e Direitos Humanos

[...] pauta-se na análise crítica e estratégica dos direitos humanos como mediação para a defesa de uma cultura política com direção emancipatória e respeito à diversidade, com a perspectiva de conhecer as reais condições de vida da população e buscar formas de intervir na defesa de direitos e contra todos os processos de degradação da vida humana. Atua como instância recursal nos julgamentos éticos e na capacitação de agentes multiplicadores, por meio do curso Ética em Movimento [...]. Atua também na divulgação do código de ética e na defesa dos princípios contidos no projeto ético-político profissional, articulando-se com movimentos em defesa dos direitos humanos (CFESS, 2014).

Considera-se que o Conselho profissional exerce um papel fundamental para o aprimoramento do exercício profissional, pois, além das suas tarefas privativas, ele também atua no sentido de promover a inserção da categoria profissional nos debates atuais perante a ideia de defesa do projeto ético-político. A proposta de trabalho em composição com a Associação Brasileira de Ensino e Pesquisa em Serviço Social (ABEPSS) e com a Executiva Nacional de Estudantes de Serviço Social (Enesso) demonstra o comprometimento do Conjunto Cfess-Cress em atrelar as diretrizes teóricas e o movimento de estudantes de Serviço Social nas discussões da categoria e na busca de proposições conjuntas para os desafios da categoria profissional.

Seguindo nessa linha, constata-se o empenho do conjunto Cfess-Cress em destacar a importância dos direitos humanos como horizonte de frente de luta (BARROCO, 2004) para o exercício profissional. Posta essa discussão, inclui-se uma análise sobre a formação profissional e a produção teórica relativa a direitos humanos como forma de explanar a importância da indissociabilidade entre a teoria e a prática.

A formação profissional em Serviço Social é permeada por um projeto que define um horizonte para a qualidade e o aprimoramento da formação com base no Projeto Ético-Político da profissão. Esse projeto foi remodelado na década de 90, mesmo período em que a profissão realizou várias transformações em seus documentos normativos. Sua elaboração foi executada de forma coletiva e articulada, sendo, dessa forma, um importante instrumento para a qualidade das atividades do tripé ensino, pesquisa e extensão, pois se constitui num "processo de qualificação teórico-metodológico, técnico e ético-político para o exercício dessa especialização do trabalho coletivo" (ABESS/CEDEPSS, 1996, p. 163).

O projeto de formação profissional indica uma base sólida para que os assistentes sociais estejam pautados nas lutas sociais, entendendo estas últimas como a capacidade dos sujeitos históricos de construírem novos padrões de sociabilidade (IAMAMOTO, 1998). Ainda se chama atenção que o projeto de formação profissional deve suscitar o envolvimento dos assistentes sociais com as classes subalternas.

[...] uma das exigências que se vislumbra na reconstrução do projeto de formação profissional é estimular a apropriação dos assistentes sociais às condições de vida das classes subalternas e de suas formas de luta e de organização. Captar as formas de explicitação social, cultural e política de seus interesses e necessidades, criadas no enfrentamento coletivo e individual de situações de vida, de experiências vivenciadas (IAMAMOTO, 1998, p. 197).

Para adentrar na discussão da formação profissional, faz-se uma análise das Diretrizes Gerais do Curso de Serviço Social (ABESS/ CEDEPSS, 1997) e da Política de Educação Permanente (CFESS, 2012a). As Diretrizes Gerais do Curso de Serviço Social expressam a base comum para a formação profissional, sendo referência para que as instituições de ensino elaborem seus currículos. Já a Política de Educação Permanente do conjunto Cfess-Cress constitui-se em um instrumento político direcionado ao fortalecimento da formação e do exercício profissional dos assistentes sociais.

As Diretrizes Gerais do Curso de Serviço Social constituem-se no documento de orientação onde são encontrados os princípios e as diretrizes para os cursos de graduação em Serviço Social. Esse documento apresenta "[...] uma lógica curricular inovadora, que supere a fragmentação do processo de ensino e aprendizagem e permita uma intensa convivência acadêmica entre professores, alunos e sociedade" (ABESS/CEDEPSS, 1997, p. 63). 
É possível verificar que as diretrizes contidas no projeto de formação direcionam para que os currículos desfrutem de uma flexibilidade através de atividades diversas, assim como há uma orientação para que esses tenham estabelecidas dimensões de ordem investigativa e interventiva, a fim de que realizem a relação entre teoria e realidade. Ao observar os princípios para a formação profissionais, elencam-se como principais o segundo, "Rigoroso trato teórico, histórico e metodológico da realidade social e do Serviço Social, que possibilite a compreensão dos problemas e desafios com os quais o profissional se defronta no universo da produção e reprodução da vida social", e o sétimo princípio, "[...] caráter interdisciplinar nas várias dimensões do projeto de formação profissional" (ABESS/CEDEPSS, 1997, p. 61).

Acredita-se que essas disposições (diretrizes e princípios) vêm ao encontro da formação em direitos humanos do Serviço Social, uma vez que orientam currículos pautados na ética profissional, no comprometimento com a teoria crítica e, junto a isso, preconizam a questão da interdisciplinaridade para a formação profissional.

A Política de Educação Permanente, realizada em conjunto com ABEPSS e com a Enesso, apresenta conceitos referentes à educação permanente voltados para o aprimoramento técnico, político e intelectual dos assistentes sociais, de forma a qualificar o exercício profissional e fortalecer a inserção propositiva e crítica no mundo do trabalho, com base no projeto ético-político do Serviço Social.

Nesse sentido, o documento também defende o enfrentamento da precarização e da mercantilização do ensino no Brasil, fazendo referência à lógica imposta, "[...] do chamado Capital Humano, [...] que reduz a noção de formação continuada a um conjunto de treinamentos esparsos, para atender às demandas mais imediatas do mercado" (CFESS, 2012a, p. 22).

Em linhas gerais, as diretrizes da Política de Educação Permanente elucidam os caminhos para a formação profissional pautada no aprimoramento intelectual crítico, pela constante reflexão sobre a realidade social, e no fortalecimento da categoria e dos Conselhos Regionais e Federal, em sintonia com o projeto ético- -político. Nesse sentido, importa mencionar que esse documento se constitui em uma ferramenta de orientação mais ampla, a qual não foca temáticas específicas trabalhadas na profissão, como é o caso dos direitos humanos.

Acredita-se que essa política já se constitui em um avanço para a categoria, no entanto, deve ser acrescida de orientações temáticas relacionadas às já explícitas no Código de Ética - , como forma de possibilitar bases para os projetos de educação permanente que venham a se constituir.

O Conjunto Cfess/Cress, a Abepss e a Enesso têm se empenhado teórica e politicamente para apreender o movimento real da sociedade em que vivemos, observando o Serviço Social na história por meio de importantes leituras e interlocuções com a teoria social crítica. Assim, a partir desse mirante de análise que as entidades têm definido suas ações e lutas (ABEPSS; CFESS, 2011, p. 798).

O Cfess publica regularmente posicionamentos políticos que elucidam temáticas ligadas ao trabalho dos assistentes sociais, através do material chamado Cfess Manifesta. Ainda que a maior parte dessas publicações diga respeito à defesa de diversos direitos, aqui serão apresentadas algumas das publicações que têm relação direta com a temática de direitos humanos. Entende-se que esses materiais produzidos têm afinidade com a formação dos assistentes sociais, de forma que as campanhas apresentam temas a serem refletidos e fazem o convite para o envolvimento na luta.

O boletim emitido pelo Cfess em 15 de dezembro de 2008 foi alusivo à $11^{\text {a }}$ Conferência Nacional de Direitos Humanos, realizada no mesmo período, e teve como título Direitos Humanos: refletir e lutar todos os dias! (CFESS, 2008). Esse material, contendo oito páginas, discute a violação dos direitos humanos a partir de exemplos trágicos, como o massacre do Carandiru de 1992, o assassinato do índio da tribo Pataxó Hã-Hã-Hãe por cinco jovens de classe média alta em 1997, a morte da adolescente Eloá Pimentel após cárcere privado pelo ex-namorado no ano de 2008 , dentre outros casos de violações pouco expostos na mídia.

A mesma publicação também elenca cinco ações estratégicas para a defesa dos direitos humanos, a saber: (a) articulação com outros sujeitos coletivos, como Movimento Sem Terra, 
movimento feminista, movimento de mulheres e homens negros, movimento LGBT; (b) Curso de Capacitação Ética Para Agentes Multiplicadores do Projeto Ética em Movimento; (c) potencialização do site do Cfess como instrumento de visibilidade da posição da entidade na defesa e na garantia dos direitos humanos; (d) realização da campanha O Serviço Social Mudando o Rumo da História: Reagir Contra o Racismo É Lutar por Direitos (realizada pelo CFESS em 2003-05), da campanha sobre a livre orientação sexual O Amor Fala Todas as Línguas - Assistente Social na Luta Contra o Preconceito (concretizada pelo CFESS em 2005-08) e da campanha Direitos Humanos, Trabalho e Riqueza do Brasil (efetivada pelo CFESS em 2008-11); e (e) participação nos espaços de representação, como conselhos de políticas e de direitos, e nos fóruns de participação e articulação, na perspectiva de defender os interesses dos segmentos do trabalho e o projeto ético-político profissional.

O Curso Ética em Movimento também é apresentado como um projeto da instituição como atividade formativa pela defesa da ética e dos direitos humanos, assim como o depoimento de profissionais sobre a temática. $\mathrm{Na}$ data dessa publicação, que também é comemorativa aos 60 anos da instituição da Declaração Universal dos Direitos Humanos, o Cfess reafirmou o compromisso com a luta por uma sociedade anticapitalista e pela emancipação humana.

Fazendo referência à $2^{a}$ Conferência Nacional de Políticas Públicas e Direitos Humanos LGBT, no ano de 2011, o Conselho lançou o Cfess Manifesta intitulado Assistentes Sociais em Defesa da Diversidade Humana (CFESS, 2011). Esse material discute o contexto atual da luta pela dignidade da população Lésbicas, Gays, Bissexuais, Travestis, Transexuais e Transgêneros (LGBT), bem como apresenta os seguintes instrumentos normativos da categoria: a Resolução CFESS n 489/2006, que estabelece normas vedando condutas discriminatórias ou preconceituosas, por orientação e expressão sexual por pessoas do mesmo sexo, no exercício profissional do assistente social, regulamentando princípio inscrito no Código de Ética Profissional, e a Resolução Cfess n $615 / 2011$, que dispõe sobre a inclusão e o uso do nome social da assistente social travesti e do(a) assistente social transexual nos documentos de identidade profissional.

Por fim, no ano de 2012, o Conselho lançou dois Cfess Manifesta relacionados à temática dos direitos humanos. No mês de setembro, foi publicado o material Serviço Social e Direitos Humanos (CFESS, 2012c), com foco especial no Seminário Nacional de Serviço Social e Direitos Humanos, e, em dezembro, a edição Sem Movimento Não Há Liberdade (CFESS, 2012b), comemorativa ao Dia dos Direitos Humanos no Brasil, dia 12 de dezembro de cada ano.

Ambas as publicações se focam no compromisso da profissão com o enfrentamento das formas de exploração e opressão que se apresentam no cotidiano profissional, bem como reforçam a importância do movimento da categoria enquanto coletivo crítico para a construção de alternativas históricas de liberdade. Isso posto, reforça-se que o conjunto Cfess-Cress vem afirmando a ideia de direitos humanos não somente nas publicações Cfess Manifesta, mas também na elaboração de atividades alusivas ao tema.

Atualmente, o tema dos direitos humanos constitui importante matéria de pesquisa tanto na área acadêmica quanto nos espaços políticos, em âmbitos nacional e internacional. Em escala mundial, são inúmeros os pesquisadores de diversas correntes teóricas que se vêm detendo no estudo desse tema (FREIRE, 2011). A categoria profissional de Serviço Social também se vem debruçando na temática de direitos humanos, tanto nas pesquisas de âmbito acadêmico quanto nos espaços profissionais e nas instâncias de controle social e formação profissional.

O Serviço Social possui, ao mesmo tempo, uma dimensão interventiva e uma dimensão intelectual. Nessa profissão, enfrenta-se o desafio de desvendar a dinâmica social e do Estado no âmbito profissional. É dessa forma que os estudos e pesquisas servem como um suporte para a articulação entre a teoria e a prática, de forma a apontar uma visão crítica. O processo de pesquisa permite o adensamento do conhecimento sobre a realidade onde se atua, configurando-se como central tanto na formação como no trabalho profissional. Além disso, o conhecimento oriundo do trabalho profissional, somado à análise teórica, confere uma intervenção mais elaborada. 
Desenvolver um exercício profissional qualificado, do ponto de vista do conhecimento, é um desafio maior, porque envolve não somente o domínio das teorias sociais, mas exige também sua contraposição com a realidade, fornecendo respostas técnicas, em vista de procedimentos. Demanda muito mais a elaboração do Assistente Social sobre os objetos do seu fazer profissional, do que somente a apropriação das teorias sociais (MANGINI, 2011, p. 114).

Como forma de expor brevemente a produção do Serviço Social relacionada ao tema dos direitos humanos, apresentam-se algumas obras que se destacaram durante o estudo sobre esse tema.

A pesquisa de Mangini (2011) demonstra que o conjunto da produção do Serviço Social em periódicos da área revela um número pequeno de produções sobre direitos humanos, se comparado ao universo de artigos publicados nessas revistas. Com relação às perspectivas teóricas identificadas, a autora revela que a produção de conhecimento de direitos humanos no Serviço Social apresenta uma pluralidade de tendências teórico-metodológicas e também afirma que o uso da perspectiva social crítica é pouco aprofundado. Com essa dedução, a autora define, portanto, que os assistentes sociais necessitam desenvolver concepções mais aprofundadas sobre direitos humanos, sobretudo relacionadas ao conhecimento sobre a relação dos direitos humanos com o exercício profissional (MANGINI, 2011).

O livro Direitos Humanos e Serviço Social: Polêmicas, Debates e Embates, organizado por Valéria Forti e Cristina Brites (FORTI; BRITES, 2013), apresenta uma coletânea de 10 artigos sobre o tema. A obra elucida os direitos humanos como um "campo epistemológico e de luta social estratégica, no horizonte de construção de uma ordem social libertária, no contexto de um campo de disputa de projetos societários" (FORTI; GUERRA, 2011, p. 37).

A Revista Katálisys, na edição Ética e Direitos Humanos (2011), traz uma série de artigos relacionados à temática da ética e dos direitos humanos a partir de diferentes quadros teóricos que oferecem óticas diferenciadas, e não, necessariamente, excludentes, de abordar o tema (OLIVEIRA, 2011). O autor, que parte de uma trajetória filosófica, defende que a abordagem do tema em distintas óticas pode contribuir para demonstrar como elas podem ser complementares "[...] mesmo guardando seus níveis teóricos diferenciados para a consideração de um tema que se transformou numa das questões centrais do mundo em que vivemos" (OLIVEIRA, 2011 , p. 147), tanto sob olhar teórico como de sua efetivação nos diversos níveis e dimensões da vida humana, pessoal e coletiva. O referido periódico apresenta artigos que discutem temas como direitos humanos e os campos do conhecimento, a constituição histórico-ontológica da ética e dos direitos humanos, a fundamentação moral dos direitos humanos e os fundamentos e contradições da ética e do Serviço Social. Outros artigos discorrem sobre a obra de autores como Karl Marx, Immanuel Kant, Jürgen Habermas e Michel Foucault. Também apresenta artigos que fazem relação entre os direitos humanos e os seguintes temas: mídia, cultura, idoso, ditadura militar, política previdenciária e de habitação.

Outra publicação relevante para os estudos de direitos humanos é o quarto volume dos Cadernos de Ética, chamado Ética e Direitos Humanos (VINAGRE; PEREIRA, 2007), onde são aprofundados os debates sobre ética e direitos humanos no contexto do Serviço Social. Esse material se constitui num apoio teórico ao Curso de Formação Ética Para Agentes Multiplicadores do Projeto Ética em Movimento realizado pelo Cfess.

A produção acadêmica tem considerado o tema dos direitos humanos e o Serviço Social, contribuindo para adensar esse debate. Para Proni (2012), esse debate, em tempos de capital-fetiche, surge com tamanha urgência como um instrumento de "[...] resistência à lógica mercadológica, e deve ser considerado como objeto de estudo e de intervenção privilegiada e estratégica de defesa à liberdade e à democratização das relações, cabível em todos os campos e espaços de trabalho do assistente social" (PRONI, 2012, p. 161).

Já a pesquisa de Dalton (2008) revela que a discussão acerca dos direitos humanos tem sido realizada de forma superficial, permitindo a fragilidade de seus fundamentos e funcionalidades na contemporaneidade.

Por sua vez, Silva (2011) constata que alguns espaços de trabalho dos assistentes sociais "[...] conferem em maior grau ao Serviço Social 
uma diversidade de questões éticas e de direitos humanos" (SILVA, 2011, p. 68), quando estão presentes questões como preconceito, aborto, diversidade sexual e religiosa, dentre outras, requerendo permanente posicionamento ético para a garantia dos direitos da população usuária desses serviços.

Essa questão tem relação com o trabalho dos assistentes sociais no acolhimento aos migrantes, sejam eles refugiados ou não, grupos de pessoas que possuem cultura e valores da sua localidade de origem e vão precisar adaptar-se em um novo país, com comportamentos e estilos de vida que muitas vezes lhes são estranhos. Tanto nos serviços "tradicionais", como, por exemplo, nas políticas de assistência social, saúde e educação, quanto nos serviços específicos de atendimento aos migrantes, o profissional, ao se deparar com a demanda trazida pelo migrante, precisará conhecer e compreender a dinâmica da realidade da migração e do refúgio, de modo a criar estratégias profissionais para oportunizar acesso a direitos, buscando a superação das violações a que esses sujeitos estão expostos.

A Federação Internacional de Assistentes Sociais possui resoluções sobre os temas dos direitos humanos (IFSW, 2000) e dos refugiados (IFSW, 1998), onde trata da importância do engajamento da profissão em ambas as causas e de estratégias para seu enfrentamento com base nos códigos de ética da profissão. A mesma instituição lançou, recentemente, uma declaração chamada Social Work Responding to The Political Crisis Forcing People into Displacement and Refugee Status (IFSW, 2016), elaborada por assistentes sociais de 26 países e representantes de refugiados, na qual propõe um plano de trabalho estratégico para o tema.

No Brasil, o Serviço Social vem dedicando-se também à produção acadêmica sobre esse tema da migração e refúgio. Monografias, artigos, dissertações e teses vem sendo recorrentes, sobretudo nos estados que possuem alto número de migração. A seguir, exibe-se uma breve amostra da produção recente do Serviço Social sobre a questão da migração ou refúgio. Enquanto trabalhos de pós-

-graduação, têm-se: Trabalho e (I) Migração: determinações do movimento migratório dos bolivianos da Cidade de São Paulo para Guarulhos (SILVA, 2012) e Refúgio, a Morada da Criatura Inacabada: reconhecimento e direitos dos povos deslocados (SALES, 2013). Como artigo acadêmico, encontra-se Serviço Social e Direitos Humanos: uma análise sobre os refugiados no Brasil (SAMPAYO, 2008); e, como trabaIho de conclusão de curso, A Migração Como Expressão da Questão Social: um estudo a partir da população atendida no Núcleo de Apoio à Família-Rodoviário (naf-r) (SCHMITZ, 2009)

Isso posto, considera-se necessária a realização de mais pesquisas sobre os direitos humanos tanto no campo teórico, considerando as diversas perspectivas, quanto no âmbito prático. Pesquisas com focos distintos são fundamentais para que a categoria de assistentes sociais e também de outras áreas possam apropriar-se de fundamentos e prerrogativas dos direitos humanos.

\section{Considerações finais}

O presente trabalho busca abordar os direitos humanos a partir de um percurso histórico, como forma de elucidar seus desdobramentos em políticas públicas nos dias atuais. Cotidianamente, presencia-se um forte ataque por parte da imprensa e da ala conservadora política, no Brasil, à ideia de direitos humanos. Esses agentes vêm distorcendo esse conceito que é tão caro na história do Mundo ocidental desde o início do liberalismo e, principalmente, nas sociedades democráticas contemporâneas. Conforme discutido, esse tema é presente no cotidiano dos profissionais do Serviço Social, mas ainda um tanto invisibilizado enquanto conceito por parte da categoria. Nesse sentido, torna-se imperativo que os assistentes sociais procurem apropriar-se do tema e manter-se atualizados frente às discussões concernentes aos direitos humanos em seu âmbito teórico e jurídico, uma vez que a sua defesa está intrinsecamente ligada à garantia dos direitos das populações atendidas.

Destaca-se a dimensão política do conjunto Cfess-Cress, ao ampliar, gradativamente, espaços para debates e atividades sobre a temática dos direitos humanos. Seja pela proposição de eventos, seja pela elaboração de materiais, as entidades, em nível nacional e nas diversas regiões, oferecem espaços de qualidade para que os profissionais de Serviço Social se apropriem 
da discussão e também busquem discutir com os seus pares como fortalecer as lutas atuais da categoria.

O tema da migração e do refúgio é central nos dias atuais, tendo vista o alto número de pessoas em situação de deslocamento, na condição de migrantes ou de refugiados. Além do mais, está claro que os processos de deslocamento estão fortemente ligados aos tensionamentos oriundos das relações do sistema socioeconômico, pautado na lógica do capital. Guerras e outras situações de conflitos nos países, sobretudo nas regiões mais pobres, estão relacionadas aos interesses das grandes organizações na indústria do armamento e na exploração de recursos naturais e também humanos, sendo assim, é imprescindível o entendimento desse processo de forma a fazer as denúncias necessárias.

Entende-se a importância das investigações que auxiliem a compreender melhor os dados existentes no Brasil sobre as migrações (número da população, relações de trabalho, acesso aos serviços públicos), uma vez que ainda existem inconsistências nas informações disponíveis, haja vista a questão da invisibilidade dos imigrantes no País. Importa mencionar também que o envolvimento em estudos e publicações de qualidade sobre o gênero podem auxiliar a criação de políticas públicas e sociais para os migrantes.

Quanto às políticas públicas para a população migrante, entende-se a importância da incorporação da realidade migratória à rotina dos diversos serviços públicos nas esferas municipais, estaduais e federal, assim como o refinamento dos serviços prestados aos migrantes, como forma de favorecer a rápida e qualificada inserção dessa população no Brasil. Sabe-se que os espaços de acolhimento ainda são muito incipientes; nesse sentido, é necessário o aprofundamento dos diagnósticos relacionados às demandas das populações migrantes no País. Além dos serviços de atendimento, deve-se fomentar a criação de mecanismos jurídicos para a prevenção de violações de direitos da pessoa migrante.

Os diversos espaços de controle social, assim como as conferências em níveis local e nacional, devem ser considerados como locais estratégicos para colocar o tema em evidência na agenda política nacional. Esses espaços democráticos têm como objetivos a proposição e a discussão dos planos e políticas públicos brasileiros.

Deve-se ter em conta os processos migratórios como um ponto positivo para a sociedade, como um dispositivo de trocas e fortalecimento de culturas e também na perspectiva do desenvolvimento econômico e social do País. No atendimento e no acompanhamento dos indivíduos ou famílias estrangeiras, devem ser pensadas formas de promover a cidadania universal, baseada na solidariedade e nas ações humanitárias, bem como o contato profissional deve buscar conciliar reciprocidade ao invés de discriminação e xenofobia, promovam-se encontros de aprendizado e convivência ao invés do choque cultural e, acima de tudo, a acolhida ao imigrante frente à situação de exclusão.

Com este artigo, pretende-se contribuir para esse debate, sem a intenção de esgotar todas as dimensões que lhe são presentes.

\section{Referências}

ALMEIDA, Wellington L. A estratégia de políticas públicas em direitos humanos no Brasil no primeiro mandato Lula. Revista Katálysis, Florianópolis, v. 14, n. 2, p. 230--238, jul./dez. 2011.

ALVES, Lindgren. Os direitos humanos como tema global. São Paulo: Perspectiva; Brasília: Fundação Alexandre de Gusmão, 1994.

ANDRADE, José Henrique Fischel de. O Brasil e a proteção de refugiados: a discussão tem início no Congresso Nacional. In: Pensando o Brasil: reflexões e sugestões para os problemas do Brasil, Brasília, ano V, n. 16, p. 7-12, set. 1996.

ASSOCIAÇÃO BRASILEIRA DE ENSINO E PESQUISA EM SERVIÇO SOCIAL (ABEPSS); CONSELHO FEDERAL DE SERVIÇO SOCIAL (CFESS). As entidades do Serviço Social brasileiro na defesa da formação profissional e do projeto ético-político. Serviço Social \& Sociedade, n.108, p. 785-802, 2011. Disponível em: http:// www.scielo.br/scielo.php?script=sci_arttext\&pid =S0101-66282011000400013. Acesso em: 20 de janeiro de 2014.

ASSOCIAÇÃO BRASILEIRA DE ESCOLAS DE SERVIÇO SOCIAL (ABESS)/CEDEPSS. Proposta básica para o Projeto de Formação Profissional. Serviço Social \& Sociedade, São Paulo, n. 50, 1996. 
ASSOCIAÇÃO BRASILEIRA DE ESCOLAS DE SERVIÇO SOCIAL (ABESS)/CEDEPSS. Diretrizes gerais para o curso de Serviço Social. Cadernos ABESS. São Paulo, n. 7, 1997.

BAENINGER, Rosana. Migrações contemporâneas no Brasil: desafios para as políticas sociais. In: PRADO, Erlan José Peixoto do; COELHO, Renata (Org.). Migrações e trabalho. Brasília: Ministério Público do Trabalho, 2015. 236p.

BARROCO, M. L. S. A inscrição da ética e dos direitos humanos no projeto ético- $\quad$-político do Serviço Social. Revista Serviço Social \& Sociedade, São Paulo, n. 79, p. 27-41, 2004.

BOBBIO, Norberto. A era dos Direitos. Tradução de Carlos Nelson Coutinho. Rio de Janeiro: Campus, 1992.

BONAVIDES, Paulo. Curso de Direito Constitucional. 4 ed. São Paulo: Malheiros, 1993.

BRASIL, Lei no 9.474, de 22 de julho de 1997. Estatuto do Refugiado. Disponível em: <http://www. planalto. gov.br/ccivil_03/leis/L9474.htm>. Acesso em: 15 mar. 2016.

BRASIL. Lei no 9.474 , de 22 de julho de 1997. Define mecanismos para a implementação do Estatuto dos Refugiados de 1951 e determina outras providências. Diário Oficial [da] República Federativa do Brasil. Disponível em: <www.planalto.gov.br>. Acesso em: 5 maio 2016.

BRASIL. Ministério da Justiça. Secretaria Nacional de Justiça. Comigrar. Texto- -Base da $1^{a}$ Comigrar. 2014. Disponível em: <http://www.participa.br/articles/ public/0006/4009/Texto_base_1a_COMIGRAR Janeiro_2014_1_.pdf>. Acesso em: 14 maio 2015.

BUCCI, Maria Paula Dallari. Buscando um conceito de políticas públicas para a concretização dos direitos humanos. In: BUCCI, Maria Paula Dallari et al. Direitos humanos e políticas públicas. São Paulo: Pólis, 2001. 60p. (Cadernos Pólis, n. 2).

CASTRO, Mary Garcia. Migrações internacionais e direitos humanos e o aporte do reconhecimento. Revista Interdisciplinar da Mobilidade Humana (REMHU), ano XVI, n. 31, p. 7-36, 2008.

CHIARELLO, Leonir Mario. Ações humanitárias para migrantes em situação de vulnerabilidade: tendências históricas, desafios atuais e compromissos do SIMN. In: Economia, parlamentos, desenvolvimento e migrações: as novas dinâmicas bilaterais entre Brasil e Europa. Tradução de Mónica Baña. Rio de Janeiro: Konrad-Adenauer-Stiftung, 2012. 240p.
COGO, Denise Maria; BADET, Maria. Guia das migrações transnacionais e diversidade cultural para comunicadores: migrantes no Brasil. São Leopoldo: Instituto Humanitas Unisinos/Instituto de la Comunicación de la UAB, 2013.

CONSELHO FEDERAL DE SERVIÇO SOCIAL (CFESS). Assistentes Sociais em Defesa da Diversidade Humana. 2011. Disponível em: http:// www.cfess.org.br/arquivos/cfessmanifesta2011_conf IgbtSITE.pdf . Acesso em: Acesso em: 12 de novembro de 2014.

CONSELHO FEDERAL DE SERVIÇO SOCIAL (CFESS). Comissão de ética e direitos humanos. 2014. Disponível em: <http://www.cfess.org.br/ arquivos/etica_e_DH.pdf>. Acesso em: $12 \mathrm{de}$ novembro de 2014 .

CONSELHO FEDERAL DE SERVIÇO SOCIAL (CFESS). Política de educação permanente do conjunto Cfess-Cress. Brasília: Cfesss, 2012a. Disponível em: <www.cfess.org.br>. Acesso em: 06 de abril de 2014.

CONSELHO FEDERAL DE SERVIÇO SOCIAL (CFESS). Sem movimento não há liberdade. In: CFESS. CFESS Manifesta. 2012b. Disponível em: <http://www.cfess.org.br/evento_cfess/evento.php>. Acesso em: 20 maio 2014.

CONSELHO FEDERAL DE SERVIÇO SOCIAL (CFESS). Serviço Social e direitos humanos. In: CFESS. CFESS Manifesta. 2012c. Disponível em: <http:// www.cfess.org.br/arquivos/cfessmanifesta2012 semdh2012-final-ALTERADO.pdf>. Acesso em: 20 maio 2014 .

CONSELHO FEDERAL DE SERVIÇO SOCIAL (CFESS). Direitos Humanos: refletir e lutar todos os dias! In: CFESS. CFESS Manifesta. 2008. Disponível em: http://www.cfess.org.br/arquivos/ CFESS_MANIFESTA_Direitos_Humanos.pdf Acesso em: 06 de abril de 2014.

CONVENÇÃO RELATIVA AO ESTATUTO DOS REFUGIADOS (1951). Disponível em: <www.acnur. org>. Acesso em: 20 fev. 2016.

COUTO, Berenice Rojas. O Direito Social e a Assistência Social na sociedade brasileira. São Paulo: Cortez, 2004.

CULLETON, A.; BRAGATO, F.; FAJARDO, S. Curso de Direitos Humanos. São Leopoldo: Unisinos, 2009.

CUNHA, Carlos. Estado democrático de direito, cidadania e os direitos humanos: problemática do pleno exercício do Estado de direito, da cidadania 
e da democracia no Brasil atual. Revista Jurídica Unigran, Dourados, MS, v. 2, n. 4, jul./dez. 2000.

DALTON, Andréa Monteiro. Os direitos humanos à luz do Código de Ética do Serviço Social e do Estatuto da Criança e do Adolescente. 2008. Dissertação (Mestrado em Serviço Social)—Pontifícia Universidade Católica do Rio de Janeiro/Departamento de Serviço Social/Programa de Pós-graduação em Serviço Social, Porto Alegre, 2008.

DECLARAÇÃO DE CARTAGENA. Conclusões e recomendações. 22 de novembro de 1984. Disponível em: <http://www.acnur.org/t3/fileadmin/Documentos/ portugues/BD_Legal/Instrumentos_Internacionais/ Declaracao_de_Cartagena.pdf?view $=1>$. Acesso em: 20 abr. 2016.

DEPARTAMENTO DE ASUNTOS ECONÓMICOS Y SOCIALES DE LAS NACIONES UNIDAS (DAES). International Migration 2013. 2013. Disponível em: <www.un.org/en/development/desa/population/ migration/publications/wallchart/docs/wallchart2013. pdf>. Acesso em: 14 abr. 2016.

DORNELLES, João R. Sobre os direitos humanos, a cidadania e as práticas democráticas no contexto dos movimentos contra-hegemônicos. Revista da Faculdade de Direito de Campos, Ano VI, No 6 junho de 2005.

FORTI, Valéria; BRITES, Cristina Maria. Direitos Humanos e Serviço Social: polêmicas, debates e embates. 3. ed. Rio de Janeiro: Lumen Juris, 2013.

FORTI, Valéria; GUERRA, Yolanda (Org.). Ética e Direitos: ensaios críticos. 3. ed. Rio de Janeiro: Lumen Juris, 2011. (Coletânea Nova de Serviço Social).

FORTI, Valéria; MARCOSIN, Cleier; FORTI, Lorena. Direitos humanos e Serviço Social: debater é preciso. In: FORTI, Valéria; BRITES, Cristina M. (Org.). Direitos humanos e Serviço Social: polêmicas, debates e embates. Rio de Janeiro: Lumen Juris, 2011.

FREIRE, Silene de Moraes. Direitos humanos no Brasil: ilusão jurídica ou possibilidade histórica? In: FORTI, Valéria; BRITES, Cristina M. (Org.). Direitos humanos e Serviço Social: polêmicas, debates e embates. Rio de Janeiro: Lumen Juris, 2011.

GLOBAL TRENDS FORCED DISPLACEMENT IN 2016. 2016. Disponível em: <http://www.unhcr. org/news/latest/2016/6/5763b65a4/global-forceddisplacement-hits-record-high.html>. Acesso em: 20 jun. 2016.
GOHN, Maria da Glória. Movimentos sociais no início do século XXI: antigos e novos atores sociais. Petrópolis: Vozes, 2003.

GORCZEVSKI, Clovis. Direitos humanos: dos primórdios da humanidade ao Brasil. Porto Alegre: Imprensa Livre, 2005.

IAMAMOTO, Marilda V. O debate contemporâneo do Serviço Social e a ética profissional. In: BONETTI, Dilsea A. (Org.). Serviço Social e ética: convite a uma nova práxis. 6. ed. São Paulo: Cortez, 2010.

IAMAMOTO, Marilda. O Serviço Social na contemporaneidade: trabalho e formação profissional. São Paulo: Cortez, 1998.

INSTITUTO DE ESTUDOS SOCIOECONÔMICOS (INESC). A política de direitos humanos no Governo Lula. Brasília: INESC, 2005.

INTERNATIONAL FEDERATION OF SOCIAL WORKERS (IFSW). Human Rights. 2000. Disponível em: <http://ifsw.org/policies/humanrights/>. Acesso em: 15 fev. 2015.

INTERNATIONAL FEDERATION OF SOCIAL WORKERS (IFSW). International Policy on refugees. 1998. Disponível em: <http://ifsw.org/ policies/refugees/>. Acesso em: 15 fev. 2015.

INTERNATIONAL FEDERATION OF SOCIAL WORKERS (IFSW). Social Work Responding to The Political Crisis Forcing People into Displacement and Refugee Status. 2016. Disponível em: <http:// ifsw.org/news/social-work-responding-to-the-politicalcrisis-forcing-people-into-displacement-and-refugeestatus/>. Acesso em: 18 jun. 2016.

LIMA JR., Jayme Benvenuto. O Caráter expansivo dos direitos humanos na afirmação de sua indivisibilidade e exigibilidade. In: PIOVESAN, Flávia (Org.). Direitos humanos, globalização econômica e integração regional: desafios do Direito Constitucional internacional. São Paulo: Max Limonad, 2002.

LUSSI, Carmen. O compromisso de associações de migrantes, organizações e academia pelos DDHH das pessoas em mobilidade. Revista Interdisciplinar de Mobilidade Humana (REMHU), Brasília, ano XXI, n. 41, p. 259-276, jul./dez. 2013.

LUSSI, Carmen. Conflitos e vulnerabilidades no processo migratório. In: MESA REDONDA MIGRAÇÕES E IDENTIDADES ÉTNICAS. Rio de Janeiro: UERJ/Faculdade de Serviço Social/Programa de Estudos de Gênero, Geração e Etnia, 10 de julho de 2009. 
LUSSI, Carmen. Conflitos e vulnerabilidades no processo migratório. SIMPÓSIO INTERNACIONAL MIGRAÇÕES E TRABALHO, 2014. Brasília: Ministério Público do Trabalho, 2014.

LUSSI, Carmen; MARINUCI, Roberto. Vulnerabilidade social em contexto migratório. 2007. Disponível em: $<$ http://www.csem.org.br/pdfs/vulnerabilidades_dos_ migrantes.pdf $>$. Acesso em: 05 de Set. de 2014.

MANGINI, Fernanda N. R. A produção acadêmica do Serviço Social sobre os direitos humanos. 2011. 135 p. Dissertação (Mestrado em Serviço Social)_ Programa de Pós-Graduação em Serviço Social, Universidade Federal de Santa Catarina, Florianópolis, 2011.

MARTINELLI, M. L. Serviço Social: identidade e alienação. São Paulo: Cortez, 1989.

MESZÁROS, István. Filosofia, ideologia e Ciência Social. Tradução de Ester Vaisman. São Paulo: Boitempo, 2008.

MONDAINI, Marco. Revolução Inglesa. In: PINSKI, Jaime; PINSK, Carla B. (Org.). História da cidadania. São Paulo: Contexto, 2011.

MONTAÑO, Carlos; DURIGUETTO, Maria Lúcia. Estado, classe e movimento social. 3. ed. São Paulo: Cortez, 2011. (Biblioteca Básica de Serviço Social, v. 5).

MOREIRA, Julia B. Direitos humanos e refugiados no Brasil: políticas a partir de 1997. Revista Interdisciplinar da Mobilidade Humana (REMHU), ano XVI, n. 31, 2008.

NADER, Luciana. O papel das ONGs no Conselho Nacional de Direitos Humanos da ONU. SUR - Revista Internacional de Direitos Humanos, ano 4, n. 7, 2007.

NETTO, José Paulo; BRAZ, Marcelo. Economia Política: uma introdução crítica. São Paulo: Cortez, 2010. (Biblioteca Básica de Serviço Social, v. 1).

OBSERVATÓRIO ACP DAS MIGRAÇÕES. Manual de investigação sobre as migrações: migrações sul-sul e desenvolvimento. Bélgica: ACPOBS, 2011.

ODALIA, Nilo. A liberdade como meta coletiva. In: PINSKI, Jaime; PINSK, Carla B. (Org.). História da cidadania. São Paulo: Contexto, 2010.

OLIVEIRA, Manfredo Araújo de. Direitos humanos no diálogo entre os campos de conhecimento. Editorial. Revista Katálysis, Florianópolis, v. 14, n. 2, p. 147149, jul./dez. 2011.
ORGANIZAÇÃO DAS NAÇÕES UNIDAS (ONU). Declaração Universal dos Direitos Humanos. 1948. Disponível em: www.direitoshumanos.usp.br Acesso em 01 de abril de 2014.

PAZ, Rosângela D. O. Trocando em miúdos. Serviço Social e Sociedade, ano XVII, n. 53, mar. 1997.

PINHEIRO, Paulo S.; NETO, Paulo de M. Programa Nacional de Direitos Humanos: avaliação do primeiro ano e perspectivas. Estudos Avançados, ano 11, n. 30, 1997.

PIOVESAN, Flávia. Direitos humanos e globalização. In: PIOVESAN, Flávia. Temas de direitos humanos. São Paulo: Max Limonad, 1998.

PRONI, Ana Paula. Serviço Social e direitos humanos: produção teórica e objetivação prática. 2012. Dissertação (Mestrado em Serviço Social)Pontifícia Universidade Católica de São Paulo, São Paulo, 2012.

REVISTA KATÁLYSIS, Florianópolis, v. 14, n. 2, p. 147-149, jul./dez. 2011.

RITT; Caroline Fockink; CAGLIARI, Claúdia T. S. Cidadania no Brasil: sua construção a partir de uma ótica humanística, voltada aos direitos humanos. In: GORCZEVSKI, Clovis. Direitos humanos, educação e cidadania: conhecer, educar, praticar. Santa Cruz do Sul: Edunisc, 2007.

RUIZ, Jefferson L. Direitos humanos: argumentos para o debate no Serviço Social. In: FORTI, Valéria; BRITES, Cristina M. (Org.). Direitos humanos e Serviço Social: polêmicas, debates e embates. Rio de Janeiro: Lumen Juris, 2011.

SALES, Maria Leila. Refúgio, a morada da criatura inacabada: reconhecimento e direitos dos povos deslocados. 2013. Tese (Doutorado em Serviço Social)_Pontifícia Universidade Católica do Rio de Janeiro/Departamento de Serviço Social, Rio de Janeiro, 2013.

SAMPAYO, Cynthia. Serviço Social e direitos humanos: uma análise sobre os refugiados no Brasil. Revista Interdisciplinar da Mobilidade Humana (REMHU), ano XVI, n. 31, 2008.

SCHMITZ, Alice. A migração como expressão da questão social: um estudo a partir da população atendida no Núcleo de Apoio à Família-Rodoviário (naf-r). 2009. Trabalho de Conclusão de Curso (Graduação em Serviço Social)—Universidade Federal de Santa Catarina/ Departamento de Serviço Social, Florianópolis, 2009. 
SILVA, Fabiana Aparecida da. Trabalho e (i)migração: determinações do movimento migratório dos bolivianos da Cidade de São Paulo para Guarulhos. 2012. Dissertação (Mestrado em Serviço Social)—Pontifícia Universidade Católica de São Paulo/Programa de Estudos Pós-Graduados em Serviço Social, São Paulo, 2012.

SILVA, Rosane Durval. Formação profissional na perspectiva da ética profissional e dos direitos humanos. 2011. Dissertação (Mestrado em Serviço Social)-Pontifícia Universidade Católica de São Paulo, São Paulo, 2011.

SPAGNUOLO, Sérgio. A opinião e o desconhecimento sobre direitos humanos. Mídia \& Sociedade Observatório da Imprensa, n. 785, 11 fev. 2014. Disponível em: <http://www.observatoriodaimprensa. com.br/news/view/_ed785_a_opiniao_e_o_ desconhecimento_sobre_direitos_humanos $>$. Acesso em: 30 maio 2014 .

TRINDADE, José Damião de Lima. Prefácio. In: FORTI, Valéria; BRITES, Cristina M. (Org.). Direitos humanos e Serviço Social: polêmicas, debates e embates. Rio de Janeiro: Lumen Juris, 2011.

VICENTINO, Cláudio; DORIGO, Gianpaolo. História Geral. São Paulo: Scipione, 1997.

VINAGRE, Marlise; PEREIRA, Tânia Maria Dahmer. Os direitos humanos e o projeto ético-político do Serviço Social. In: VINAGRE, Marlise; PEREIRA, Tânia Maria Dahmer.. Ética e Direitos Humanos. Curso de capacitação ética para agentes multiplicadores 2. ed. Brasília: CFESS, 2007. 